\title{
Strategies for Engaging and Communicating with Elected Officials'
}

\author{
Ricky W.Telg and Shelli D. Rampold ${ }^{2}$
}

This EDIS document is part of a series on communicating with elected officials. The series includes the following EDIS documents:

- Speaking with Policymakers about Current Issues (http:// edis.ifas.ufl.edu/wc152)

- Communicating with Local Elected Officials (http://edis. ifas.ufl.edu/wc316)

- Visiting Elected Officials (http://edis.ifas.ufl.edu/wc318)

\section{Introduction}

The EDIS publication Communicating with Elected Officials provided an overview of why communicating with elected officials is important, Extension faculty members' roles as educators regarding agricultural and natural resources (ANR) issues, and Florida county commissioners' use of information sources when gathering information about ANR issues. This publication details a strategy for those who are seeking to engage and communicate with elected officials. To engage elected officials, you should conduct the following activities:

- Build rapport/establish a relationship.

- Focus on impact.

- Identify stakeholders' values and key issues.

- Prepare and tell your story.
- Incorporate visits and educational materials.

\section{Building Rapport}

Building rapport with an elected official is important. Rapport is a characteristic of a relationship that involves a high degree of attention, a high degree of empathy, and a shared set of common expectations among engaged parties (Coan, 1984). Attention requires active listening and includes behavioral skills such as eye contact, physical posture, and the appropriate use of verbal following behavior (e.g., using a mix of open or closed questions, summarizing, and paraphrasing). Empathy involves demonstrating warmth and respect, giving detailed and specific attention, and being genuine. Establishing common expectations involves developing a mutual understanding of the topic at hand, your wants and needs, and the elected official's ability to meet those wants and needs (Coan, 1984).

To develop a rapport with elected officials, ask yourself these questions:

- Can you maintain the elected official's attention? Are you prepared with summarized information? Can you paraphrase your background and concerns to provide a thorough yet brief overview of your situation? Do you have appropriate questions for engaging the elected official? Are you prepared to answer questions they may have for you?

1. This document is AEC661, one of a series of the Department of Agricultural Education and Communication, UF/IFAS Extension. Original publication date December 2018. Visit the EDIS website at https://edis.ifas.ufl.edu for the currently supported version of this publication.

2. Ricky W. Telg, professor, Department of Agricultural Education and Communication, Center for Public Issues Education in Agriculture and Natural Resources; and Shelli D. Rampold, research coordinator, Center for Public Issues Education in Agriculture and Natural Resources; UF/IFAS Extension, Gainesville, FL 32611.

The Institute of Food and Agricultural Sciences (IFAS) is an Equal Opportunity Institution authorized to provide research, educational information and other services only to individuals and institutions that function with non-discrimination with respect to race, creed, color, religion, age, disability, sex, sexual orientation, marital status, national origin, political opinions or affiliations. For more information on obtaining other UF/IFAS Extension publications, contact your county's UF/IFAS Extension office. 
- Can you demonstrate and evoke empathy? It is important that you be prepared to speak about an issue that may be sensitive for you. Can you do so while displaying positive regard, respect, and genuineness?

- What do you have in common? Who do you know that they know? What is their hometown? What policy issues do you both support? Establishing a common link helps you build rapport (Cairney \& Kwiatkowski, 2017; Coan, 1984).

- Are you in their district/area? As elected officials' choices are often made to support their interest in being reelected, elected officials may be more likely to engage with and respond to individuals from their district (Brownson, Royer, Ewing, \& McBride, 2006; Segal \& Brzuzy, 1998). This is also important for establishing appropriate expectations of what the elected official is capable of doing for you.

\section{Establishing and Maintaining Relationships}

Developing a rapport is particularly important in that it is a means of establishing a relationship with the elected official. In the world of policymaking, relationships are key. As noted by the National Democratic Institute ([NDI], 2008), relationships between elected officials and constituents are important for fostering trust and establishing connections between citizens and their government. However, developing a relationship with an elected official may take time and require regular, ongoing communication (FHL Bank, n.d.). Elected officials' daily schedule can be packed tightly, leaving little time for lengthy discussions and explanations (Brownson et al., 2017). If you view relationship-building with an elected official as a long-term process, you may feel less pressure to try to communicate a large amount of information in a very short period of time.

Following are suggestions on how to establish and maintain relationships with elected officials:

- Visit their local office. If it is a state or federal elected official, visit the legislator at the state or national capital, as well.

- Connect with staff members. Elected officials rely on their staff members for information (Brownson et al., 2017; Jackson-Elmoore, 2005). Constituents who take the time to present their position make an impression on a staff person and, therefore, reach the elected official (Segal \& Brzuzy, 1998).
- Communicate throughout the year. You should connect with elected officials throughout the year, rather than only during a time of crisis when you need them.

- Invite them to local events and programs. If they attend the event, take a photo of them, post the photo on social media, and tag them in social media. In a guide created for legislators, the NDI (2008) encouraged elected officials to pursue activities such as these to help strengthen the notion that government serves the people.

- Send fliers, fact sheets, or e-newsletters about events and programs. For more information on elected officials' preferred methods of communicating and receiving information, please see article one in this series, Speaking with Policymakers about Current Issues (http://edis.ifas. ufl.edu/wc152).

\section{Focus on Impact}

Numbers and impact matter in elected officials' decisionmaking. An impact can be described as a reportable, quantifiable difference or potential difference a program makes in real people's lives, in such areas as economy, health, and environment (The Ohio State University, 2018). Following are some suggestions on how to focus on impact in your communication with elected officials:

- Keep it simple. An elected official may be an expert in a particular area based on his or her professional background (doctor, lawyer, farmer, teacher), but may be less knowledgeable in other areas. When communicating with elected officials, err on the side of providing information that is too simple rather than too complex.

- Provide key numbers, such as community statistics, program participation numbers, or subgroups reached (children, older adults).

- Make the data real-world. Use descriptive words to paint a picture of what it means (e.g. one in four children; two times more likely; doubled the intake of fruits and vegetables").

- Provide aggregate data. Be selective and use only a few key statistics (e.g. "how much of XX was saved" or "how many participated").

- Use visuals or infographics in written materials. Most people remember visuals, such as photographs, video, and simple informational graphics, rather than complex numbers.

- Tell stories that have impact. Weave impactful data info your story, such as workforce preparation, efficient use of resources, and economic development. 
Tell the local story. What's the local impact? Elected officials are especially interested in individuals' stories from their home districts. Finding individuals who can provide testimonials of how Extension programming helped them (such as farmers or 4-H members) is one way of telling "the local story."

\section{Identify Their Values and Key Issues}

Elected officials devote time to issues they value; sometimes these can be identified by the organizations of which they are members or volunteers. At the state and federal levels, the committees on which legislators serve are indicative of issues important to them. Many legislators list the committees they serve on or the issues that are important to them on their websites. At the federal level, the full list of committees is provided at https://www.house.gov/committees; from there, you can click on each committee and find out the committee's membership. Understanding what key issues are central to elected officials and identifying what they value are important as you communicate your issue to an elected official (Cairney \& Kwiatkowski, 2017).

While science-based, factual information is important in elected officials' decision-making, value-oriented topics are important as well:

- Elected officials often draw from emotions and employ heuristics to make decisions (Cairney \& Kwiatkowski, 2017).

- Value-oriented messages help establish personal relevancy (Cairney \& Kwiatkowski, 2017).

- Visually compelling messages can have more impact than text-only and can help reduce information overload (Brownson et al., 2006).

- Hearing stories from those impacted on an issue matters (Jackson-Elmoore, 2005).

- Agriculturalists (farmers, ranchers) are trusted sources.

- Scientists are also trusted.

\section{Prepare and Tell Your Story}

This section provides recommendations on how to prepare and tell your story to elected officials. For more detail on the concept of creating personal narratives, please read the EDIS series titled Storycrafting (http://edis.ifas.ufl.edu/ topic_story_crafting), which consists of these publications:

- Story Development (Telg, Jones, \& Telg, 2015a)

- Letting Them In: Sharing Your Story with People Outside of Your Industry (Telg, Jones, \& Telg, 2015b)

- Face-to-Face Storytelling (Telg, Jones, \& Telg, 2015c)

- Storytelling Through Social Media (Telg, Jones, Telg, \& Raulerson, 2015)

\section{Why Story is Important}

Crafting and successfully sharing your story can help you make an emotional connection. If you can elicit a positive emotional response from individuals, they will be more likely to remember you and how you made them feel. Therefore, it is preferable to have someone who has been impacted by an issue or will be impacted by a proposed policy tell their story.

\section{What to Say}

- Make simple and specific statements.

- Avoid jargon. Ask yourself, will people understand?

- Stick to the facts (science). Appealing to elected officials values and emotion can elicit a powerful response; however, this does not mean you should utilize emotional arguments or unsubstantiated opinions when presenting information to elected officials. Rather, present the facts and use those facts to explain how the situation may impact you.

- Never stretch the truth. You risk losing your credibility. It is better to say, "I don't know," and then get back to the person later, rather than try to make something up in the moment.

- Prepare two to three communication points you want to convey. To best prepare the communication points you wish to convey, you should (a) make a list of the questions you anticipate will be asked, (b) be prepared to use those questions to launch your communication points, (c) write three sentences you could use to convey each communication point, and (d) develop at least one answer you can give in 20 seconds or less. 


\section{What Goes in a Story}

Three elements should be incorporated into your story:

- Who is the lead character (the protagonist)?

- What is the goal of your story? What is the lead character trying to accomplish?

- What roadblocks or barriers must the lead character overcome to accomplish this objective?

A well-developed story generally includes:

- Expressive details

- Multiple obstacles

- Logical progression or action

- A worthy goal

A well-organized story should follow the AABT formula (And, And, But, Therefore) (Telg, Jones, \& Telg, 2015a):

- And. The first "And" connects points of your story, helps the audience picture you and your goal.

- And. The second "And" prompts you to add more details.

- But. Conveys the challenge or roadblock you are trying to overcome.

- Therefore. Tells how you plan to overcome your problem and what you hope will be the result.

\section{Sharing Your Story}

- Analyze your audience.

- Tailor the story to the audience.

- Include a primary message the audience can relate to.

- Match your story to the audience you are targeting.

- Focus on a primary point.

- Emphasize this message strongly.

- Support your core message with the details of your story.

- Create the emotional connection.

\section{Incorporate Visits and Educational Materials}

A personal visit can provide an immediate impact and long-lasting impression upon an elected official. The EDIS publication Visiting Elected Officials provides recommendations for having a successful visit with elected officials.

\section{Summary}

This document highlighted the strategy for stakeholder engagement, which consists of developing a rapport/ relationship with elected officials, focusing on impact, identifying stakeholders' values and key issues, preparing and telling your story, and incorporating visits and educational materials. By following these suggestions, you will be able to more effectively engage with and communicate information to elected officials.

\section{References}

Brownson, R. C., Royer, C., Ewing, R., \& McBride, T. D. (2006). Researchers and policymakers: Travelers in parallel universes. American Journal of Preventative Medicine, 30(2), 164-172. doi:10.1016/j.amepre.2005.10.004

Coan, J. (1984). Rapport: Definitions and dimensions. Advances in Consumer Research, 11(1), 333-336. Retrieved from http://acrwebsite.org/volumes/6269/volumes/v11/ NA-11

Cairney, P., \& Kwiatkowski, R. (2017). How to communicate effectively with policymakers: Combine insights from psychology and policy studies. Palgrave Communications 3(1). doi:10.1057/s41599-017-0046-8

FHL Bank. (n.d.). Developing a relationship with your representatives and senators. Pittsburgh: PA. Author.

Jackson-Elmoore, C. (2005). Informing state policymakers: Opportunities for social workers. Social Work 50(3), 251-261. doi:10.1093/sw/50.3.251

National Democratic Institute. (2008). Constituent relations: A guide to best practices. Washington, DC.

Telg, B., Jones, J., \& Telg, R. (2015a). Story development. AEC553. Gainesville: University of Florida Institute of Food and Agricultural Sciences. http://edis.ifas.ufl.edu/wc215

Telg, B., Jones, J., \& Telg, R. (2015b). Letting them in: Sharing your story with people outside of your industry. AEC554. Gainesville: University of Florida Institute of Food and Agricultural Sciences. http://edis.ifas.ufl.edu/wc216

Telg, B., Jones, J., \& Telg, R. (2015c). Face-to-face storytelling. AEC555. Gainesville: University of Florida Institute of Food and Agricultural Sciences. http://edis.ifas.ufl.edu/ wc2 17 
Telg, B., Jones, J., Telg, R., \& Raulerson, B. (2015). Storytelling through social media. AEC556. Gainesville: University of Florida Institute of Food and Agricultural Sciences. http:// edis.ifas.ufl.edu/wc218

The Ohio State University (2018). Tips for impact writing. Marketing and Communications. College of Food, Agricultural, and Environmental Sciences. Columbus, $\mathrm{OH}$. Retrieved from https://communications.cfaes. ohio-state.edu/resources/marketing-and-brand-strategy/ tips-impact-writing

Segal, E. A., \& Brzuzy, S. (1998). Social welfare policy, programs, and practice. Itasca, IL: F. E. Peacock. 